\title{
Tracers of modern technoscience
}

\author{
Néstor Herran $\left({ }^{*}\right)$ and Xavier Roqué $\left({ }^{* *}\right)$ \\ (*) Centre d'Història de la Ciència (CEHIC). Universitat Autònoma de Barcelona. \\ nestor.herran@uab.es \\ ${ }^{(* *}$ Centre d'Història de la Ciència (CEHIC). Universitat Autònoma de Barcelona. \\ xavier.roque@uab.cat
}

Dynamis

[0211-9536] 2009; 29: 123-130

Together with genes, drugs or standardized laboratory mice, isotopes might well be considered amongst the scientific objects that shaped science, technology, and medicine in the 20th century ${ }^{1}$. Isotopes are forms of the same element that differ in the number of neutrons in their nuclei. Chemically identical yet physically distinct, ever since the end of World War II they have been widely applied to scientific research, medical diagnosis and therapy, and industrial control processes. The production, distribution and uses of isotopes have therefore borne witness to key aspects of modern technoscience, such as the role of state agencies vis-à-vis private companies and the market, or the relation between science, politics and the military. Affording a specific view of these developments, isotopes work as tracers of modern technoscience that invite historical research.

This invitation has not altogether been lost on historians of science and technology. A number of studies, some by contributors to this volume, tell us about their role in the establishment and legitimisation of national nuclear programmes, or the creation of disciplines such as biochemistry and molecular biology. These studies are referred to below, in connection with the main themes of this collection. Still missing, however, is a comparative and comprehensive transnational approach to the rise and impact of isotope science. John Krige recently exemplified such an approach in the form of a «Cold War fable based on fact», which traced the journey of a sample of

1. On epistemic and scientific objects, see Daston, Lorraine, ed. Things that talk. Object lessons from art and science. New York: Zone Books; 2004. 
phosphorus-32 from the US Atomic Energy Commission Clinton Laboratories at Oak Ridge, to a hospital ward in Trieste, Italy, in 1949. The fable was intended to display isotopes as instruments of American hegemony in Europe in the postwar years, and wrapped together diplomatic history and the history of science, in different national contexts ${ }^{2}$.

The nine papers collected in this issue on the history of isotopes are set to provide a broader, more substantial basis for historical analysis and reflection on the subject. The issue traces the biography of isotopes from their inception as objects of scientific enquiry, through their role as tools that enable research («research-technologies», in Terry Shinn and Bernward Joerges' sense) up to their transformation into technoscientific commodities and diplomatic assets ${ }^{3}$. This life of isotopes cuts across a number of themes, and is not narrowly bounded to a particular time or place. The papers it contains explore the multifarious nature of isotopes, not just at the scientific centres of research and production, but also in scientifically peripheral countries such as Hungary or Spain. Neither do they end or begin with World War II, but rather seek to provide some balance and prompt comparisons. One consequence of our approach is that the papers are not easily grouped, and we will briefly present them around a few key salient issues: emergence, the role of the state, public legitimisation, and economy.

The first papers in the collection, those by Jeff Hughes and Gabor Palló, deal with the emergence of isotopes and their applications. British radioactivist Frederick Soddy crafted the word «isotope» in 1912 to account for the chemical identity of two distinct radio-elements, ionium (thorium234) and thorium (thorium-232). Ten years later, the concept had proved its value throughout the periodic table, thanks to Francis Aston's experimental work with mass spectroscopes that were designed to reveal new elements. Soddy and Aston won the 1921 and 1922 Nobel Prizes for Chemistry, respectively -if not naturally. Even though the received historical account

2. Krige, John. The politics of Phosphorus-32: A cold war fable based on fact. Historical Studies in the Physical and Biological Sciences. 2005; 36 (1): 71-91. See also Krige, John; Barth, Kai-Henrik, eds. Global power knowledge. Science and Technology in international affairs. Chicago: University of Chicago Press [Osiris 21]; 2006, and Krige, John. American hegemony and the postwar reconstruction of science in Europe. Cambridge, MA: MIT Press; 2006.

3. Daston, Lorraine, ed. Biographies of scientific objects. Chicago and London: The University of Chicago Press; 2000; Joerges, Bernward; Shinn, Terry, eds. Instrumentation: Between science, state, and industry. Dordrecht: Kluwer Academic Press; 2001. 
Dynamis 2009; 29: 123-130

takes these events to be self-evident, Hughes unveils the work and effort that went into forging the relationship between the isotopic interpretations of matter, Rutherford' nucleus, Bohr's model of the atom, and Aston's results. Bolstered by the Nobel Prizes and experimental coherence, this basic framework did not change substantially over the following decades, but instead proved capable of incorporating the nascent quantum mechanics. Isotopes were originally related to radioactive science, and these ties were later extended to nuclear science.

The radioactive origin was also evident in the instrumental domain. Geiger's electrical method, the scintillation chamber and mass spectroscopy, technologies developed in the 1910s and 1920s, underwent significant improvements in terms of precision and reliability, and yet remained in place for decades ${ }^{4}$. Gabor Palló shows in his contribution to this volume that isotope tracing, a key technique in the deployment of isotopes, was initially developed in the 1910s by George Von Hevesy prior to any clear conceptualization of isotopy. Even though the tracer method was almost immediately apparent, its use was not generalized until the 1930s, when tracing techniques were extended by German biochemist Rudolf Schoenheimer to include light isotopes, and massively spread after WWII thanks to training programmes promoted by nuclear research establishments ${ }^{5}$.

The design and construction of the first particle accelerators in the 1930s, together with the discovery of artificial radioactivity by Irène and Frédéric Joliot-Curie in 1934, made it possible to artificially produce radioisotopes, which were soon recognized as relatively inexpensive substitutes for expensive, naturally mined radioactive elements. Natural isotopic species continued to be identified and used. Yet the rise of nuclear physics and the potential of cyclotrons as isotope sources brought about new regimes of knowledge and material production, regimes that preconfigured Big Science ${ }^{6}$. The attendant economic possibilities of

4. On the Geiger-Müller counter, see Trenn, Thadeus J. The Geiger-Müller counter of 1928. Annals of Science. 1986; 43: 111-135. On scintillation counters, see Rheinberger, H.-J. Putting Isotopes to work: liquid scintillation counters, 1950-1970. In: Joerges; Shinn, n. 3, p. 143-174.

5. Kohler, Robert E. Rudolf Schoenheimer, Isotopic tracers and Biochemistry in the 1930s. Historical Studies in the Physical Sciences. 1977; 8: 257-298.

6. Galison, Peter; Hevly, Bruce, eds. Big Science: The growth of large-scale research. Stanford: Stanford University Press; 1992; James H. Capshew; Rader, Karen A., eds. Science after '40. Osiris, 2nd Series. 1992; Hughes, Jeff. The Manhattan Project. Big Science and the atom bomb. Cambridge: Icon Books; 2002. 
mass production, distribution and use were clearly visible to scientific entrepreneurs such as Ernest O. Lawrence and Enrico Fermi. Most of these developments were closely tied to the potential applications of radioactive isotopes to medicine. As argued by Soraya Boudia in this volume, if we take into account areas like radiotherapy, there is a noticeable continuity of isotope-based medical practices during the war. There, the main transformations involved the replacement of radioactive sources (cobalt-60 instead of radium) and the emergence of new applications in the areas of diagnosis and imaging.

The replacement of the former private-managed, radium-based economy with a state-controlled isotope economy in radiotherapy studied by Boudia is paradigmatic of the main transformation of isotope science into large-scale technoscience, thanks to the impulse for nuclear matters during the war. In the post-war years, nuclear science became one of the centrepieces of cold war politics and the state became the main driving force behind isotope research, leading to an unprecedented growth in resources. Nuclear establishments such as the American AEC, the British UKAEA and the French CEA emerged as the most important actors in the reconfiguration of isotope sciences by means of the establishment of national isotope distribution programmes, as shown by Angela Creager in relation to the American programme, and Matthew Adamson and Soraya Boudia in relation to that of France ${ }^{7}$.

In the late 1940s and early 1950s, science, and nuclear science in particular, had become a major asset in Cold War politics. Secrecy reconfigured the incipient system of patents regulating isotope-related innovations, as well as related industrial developments. In his contribution, Simone Turchetti shows, for example, that the nuclear agencies' monopoly over the products of research and development was accompanied by the establishment of a

7. Other studies on the emergence of isotope distribution programmes published elsewhere are, on the United States case: Creager, Angela. The industrialization of radioisotopes by the U.S. Atomic Energy Commission. In: Grandin, Karl; Wormbs, Nina; Widmalm, Sven, eds. The science-industry nexus: History, policy, implications. Proceedings of Nobel Symposium 123. Sagamore Beach. MA: Science History Publications; 2004, p. 143-167; on the British programme, the most recent account is: Kraft, Alison. Between medicine and industry: Medical Physics and the rise of the Radioisotope 1945-65. Contemporary British History. 2006; 20: 1-35; on the French programme: Gaudillière, Jean Paul. Normal pathways: Controlling isotopes and building biomedical research in postwar France. Journal of the History of Biology. 2006; 39: 737-764. 
closed system of intellectual property management. In turn this led to a major decrease in the number of patent applications related to isotopes. A previous patent, like Fermi's for isotope production, were challenged by new legislation and led to prolonged litigations. The distribution of isotopes was also subject to restrictions derived from their strategic value. Creager's article in this volume reveals the forces shaping American politics on the distribution of isotopes before the Atoms for Peace campaigns of the mid 1950s. She portrays the clash between different sensitivities regarding the spread of isotopes in the scientific community and policymakers. Conservatives advocating for secrecy and a tighter control of civil uses of nuclear energy were confronted with more nuanced views, which stressed the importance of «restoring a sense of the international fraternity of knowledge» to hold up alliances with Europe in the spirit of the Marshall Plan. The resistance in the US to disseminate isotopes and knowledge about them, however, soon yielded to the demand for widespread industrial and medical applications ${ }^{8}$.

Among the reasons for this change of attitude was the need to legitimate nuclear programmes and the onset of the Atoms for Peace campaign, aimed at controlling the spread of nuclear technology internationally ${ }^{9}$. Isotopes soon became central elements of the nuclear energy imaginary, involving images such as the reactor as the crucible of modern society, or comparisons between nuclearisation and electrification (hence, the word «nucleonics» as a counterpart of electronics). As suggested by Hughes, these images have been strong enough to shape the historiography of radioactivity and nuclear

8. Angela Creager's analysis is an extension of a previous paper on this topic: Creager, Angela. Tracing the politics of changing postwar research practices: The export of «American» radioisotopes to European biologists. Studies in History and Philosophy of the Biological and Biomedical Sciences. 2002; 33: 367-388. Néstor Herran has showed that similar considerations can be found in training programmes. See: Herran, Néstor. Spreading nucleonics: the Isotope School at the atomic energy research establishment, 1951-1967. British Journal of the History of Science. 2006; 39 (4): 569-586.

9. On the Atoms for Peace campaign, see Krige, John. Atoms for Peace, Scientific internationalism and scientific intelligence. In: Krige; Barth eds., n. 2, p. 161-181; Krige, John. The peaceful atom as political weapon: Euratom and American foreign policy in the late 1950s. Historical Studies in the Natural Sciences. 2008; 38 (1): 5-44; Krige, John. Techno-utopian dreams, techno-political realities: The education of desire and the peaceful atom. In: Gordin, Michael; Prakash, Gyan; Tilley Helen. Utopia/Dystopia: Historical conditions of possibility. Princeton: Princeton University Press (forthcoming); Pilat, Joseph F.; Pendley, Robert E.; Ebinger, Charles K., eds. Atoms for peace. An analysis after thirty years. Boulder: Westview Press; 1985. 
science. In her contribution to this volume, Boudia argues that the highly advertised medical applications of isotopes played an important role in the social legitimisation of nuclear energy, which aimed to counteract the increasing implication of nuclear energy with its military uses. This active promotion in the public sphere is contrasted, however, with the limited assessment of therapeutic uses. On a similar vein, Adamson's paper studies the products irradiated in the first French reactors, and clearly reveals the orientation of the French nuclear programme to bomb-grade plutonium production and its minor commitment to isotope production. Francesc Barca's article shows that the spread of the industrial use of isotopes in Spain benefited from the regime's interest in promoting an image of modernity. At the same time, stressing the peaceful side of nuclear energy reinforced the rhetoric of Franco's dictatorship as a guarantor of peace in an ideologically divided country. The Spanish case is also revealing of the importance of the international distribution of isotopes as a tool for building alliances with friendly states. As shown by Maria Jesús Santesmases in her study of the history of Spanish endocrinology, imports of radioiodine by Spanish clinicians and researchers were an important agent in the recovery of the regime's international relations ${ }^{10}$.

According to Néstor Herran, isotope sciences were the shop window of nuclear establishments in the late 1940s and early 1950s, when nuclear power did not yet seem to be a feasible option. Even so, isotopes had a huge impact on medical, industrial and scientific practices. Investment in nuclear technology was so important that even the small amount of resources invested in isotope sciences served to reconfigure whole academic research areas. Either as research tools or research-enabling technologies, isotopes were crucial elements in the reconfiguration of scientific disciplines and interdisciplinary relationships after WWII, playing a particularly relevant role in the rise of such disciplines as molecular biology ${ }^{11}$. Herran's article in this volume provides a quantitative assessment of the impact of isotopes

10. See also Santesmases, María Jesús. Peace propaganda and biomedical experimentation: Influential uses of radioisotopes in Endocrinology and Molecular Genetics in Spain (19471971). Journal of the History of Biology. 2006; 39: 765-796.

11. See, for example, Rasmussen, Nicolas. The midcentury biophysics bubble: Hiroshima and the biological revolution in America, revisited. History of Science. 1997; 35: 245-93; Lenoir, Timothy; Margherite Hays. The Manhattan Project for biomedicine. In: P. R. Sloan, ed. Controlling our destinies: Historical, philosophical, ethical, and theological perspectives on the Human Genome Project. South Bend, Indiana: University of Notre Dame Press; 2000, p. 19-46; Strasser, 
on science by comparing the volume of publications involving isotopes in different disciplines, which reveals the huge impact of these instruments on biomedicine. His comparative analysis also shows that the number of publications related to isotopes increased much faster than the number of publications in most scientific fields, and he relates this to the increase in the number of scientists working in this area as a result of training programmes organised by nuclear research establishments. The multiplication of users was directly related to the multiplication of applications. In the 1950s and 1960s, isotopes were actively deployed in various guises: as tracers and producers of radiation in biomedical research, in diagnosis and therapy, and in industrial research and process control. These industrial uses, despite being less prominent in the public sphere, involved vast amounts of resources and people. This line of reasoning is reinforced by Barca, who describes the spread of the industrial applications of isotopes in Spain, and how these developments were locally appropriated to solve perceived local needs (for instance, the irradiation of foodstuff for the Spanish food industry).

The extension of isotopes to these areas, however, was only possible because distribution programmes were not constrained by the market. Huge investments by the atomic powers in nuclear programmes created a «alse» economy of isotopes which effectively subsidized radioactive materials and made them available at delivery, rather than production, cost. As well as national security and the nuclear monopoly disrupting the economy of patents, as shown by Turchetti, low isotope prices fostered demand while disregarding true production costs. In the case of medicine, Boudia provides a good example by studying the replacement of radium in radioteletherapy with cobalt-60, which had a shorter half life and was dependent on reactors for production. This replacement of former radioactive materials with reactor-made radioisotopes and the opening of new markets in the medical and industrial domains formed the basis for the current isotope economy, in which private companies like Amersham (now part of GE Healthcare) and Nordion came to play an important role in the 1980s and 1990s.

We are still a long way from exhausting the potential of isotopes to enlighten our understanding of 20th century science, technology and me- 
dicine. As some of the contributors have stated in their articles, we would like to know more about such important topics as, for example, the transition from the radium industry to the isotope industry, Eastern European developments during the Cold War, the emergence of private companies operating in this field, the public image of isotopes, or the effects of particular isotopes on the reshaping of research fields outside biomedicine. However, we believe we will have succeeded if this volume complements previous insights into the history of isotopes and provides a guide to our current knowledge of their history.

\section{Acknowledgments}

The papers collected in this issue were first presented at a workshop organized by the authors and hosted by the Centre d'Història de la Ciència (CEHIC) at the Universitat Autònoma de Barcelona (Spain) in December 1-3, 2005. We acknowledge the financial help of the «Acciones Especiales» programme of the Spanish Ministry of Education and Science (HUM200421-21493-E/HIST), and of the research group «Francesc Salvà: Història de la Ciència, la Tecnologia i la Medicina» (2002 SGR-00097); the meeting was also supported by the Catalan Society for the History of Science and Technology (SCHCT). We thank the participants and especially Soraya de Chadarevian, Alexander von Schwerin, Alison Kraft, Agustí Nieto-Galan and Jon Arrizabalaga for their comments. We also thank the contributors for their continued involvement with the project, the anonymous referees for their comments on the individual papers, and Oliver Hochadel and Simone Turchetti for their comments on this introduction. 